\title{
Determinants of Safety and Liveability in Kumasi and Tamale Metropolitan Areas in Urban Ghana
}

\author{
Ernest Bagson \\ (Corresponding Author) \\ University for Development Studies, Wa Campus, Ghana \\ ebagson@gmail.com \\ George Owusu
}

Institute of Statistical, Social, and Economic Research, University of Ghana, Legon.

\section{Martin Oteng-Ababio}

Department of Geography and Resource Development, University of Ghana, Legon

DOI//http://dx.doi.org/10.4314/gjds.v16i2.5

\begin{abstract}
This article examines the determinants of residents' perception of local level safety of life and property in an environment of rapid urbanisation and limited governments' efforts to adequately secure urban Ghana. In a survey of 1,335 respondents, 54 key informants and 12 focus group discussions, the results, from binary logistic regression and thematic analyses, indicate a generally safe urban space but varied individual and neighbourhood level determinants of safety of life and property. However, there is no statistically significant difference in the determinants and construction of safety across the three socioeconomic neighbourhoods in the metropolises partly because of blur territoriality between settlements in the cities. The paper recommends collaboration between home/land owners and urban planners as one of the surest way of improving neighbourhood boundaries and perception of safety.
\end{abstract}

Keywords: Urbanisation, Neighbourhood, Safety, Life and Property, Built Environment, Urban Ghana

\section{INTRODUCTION}

The global experience of urbanisation in the twenty first century is eminent and variedly noted. The United Nations Human Settlements Program (UN-HABITAT) 
described the twenty first century as the "Century of the City" whilst Kofi Annan former Secretary General of the United Nations (UN) - referred to the twenty first century as the "urban millennium" in his address during the world conference on cities in Berlin titled "Urban 21" in the year 2000. Also, the president of the World Watch Institute, Lester R. Brown, predicted the dominance of the urban built environment in the twenty first century by titling mankind within the period as "an urban species". Such expressions reinforce the global nature of urbanisation in the twenty first century even though the UN-Habitat, (2010) indicates that the rapid pace of urbanisation and its ramifications are globally unequal. For instance, whereas urbanisation has been generally synonymous with industrialisation in the global north, the opposite appears to be the case in the global south (Pacione, 2009; Lange, 2009; Zeng, 2010). Remarkably, the earth had an equal proportion (50\%) of urban and rural inhabitants in the year 2008 but projected to be 65 percent urban by 2050 (UN DESA, 2014). Outstandingly, a significantly large proportion of urban population will reside in the developing world especially in Asia and Africa (UNHabitat, 2012; UN, 2014) even though some scholars question the validity of the data portraying the exceptional nature of urbanisation in the developing world (Pott, 2009; 2012; UNDESA, 2012).

Nevertheless, UN-Habitat (2012) in its global report on human settlements 2007 indicates that the rapid pace of urbanisation is most pervasive in small towns of less than 500 inhabitants and medium size cities of between 1 million and 5 million inhabitants. By this estimated population cap, small and medium size cities are increasingly adding up to the global south urban hierarchy due to natural increase, rural urban migration and to some extend urban annexation or reclassification (Songsore, 2009; Zeng, 2010) "yet, these are regions whose institutions - including planning, criminal justice, social service and infrastructure systems - are least equipped to deal with rapid urbanisation" (UN-Habitat, 2012: 68). In many cases, access to urban services - health, education, sanitation, electricity, including security services is unequal (Zeng, 2010; Oteng-Ababio \& Melara, 2014; Moser, 2018).

Notably, the rate of urbanisation increases with prevalence of crime and public perception of insecurity (Kreager, et al., 2011; UN-Habitat, 2012; Moser, 2018) but does not necessarily suggest a linear relationship (Gilbert, 1999). Similarly, as the pace of urbanisation increases, over time, in Ghana (GSS, 2013), the rate of reported cases of crime increases (GPS, 2014) cognisance of the limitedness associated with police crime data (Maguire, 2012; Tankebe, 2013; Oteng-Ababio et al., 2016). For instance, whereas Ghanaian urban population increased by 52 percent from 1984 to 2000 (GSS, 2013), reported cases of crime increased by 26 percent from 1980 to 1999 (GPS, 2014). In recent times, the gap between urban population growth and that of 
reported cases of urban crime is becoming narrower than before, whereas the urban population of Ghana increased by 34 percent between 2000 and 2010, reported crime cases between 2000 and 2010 increased by 35 percent (GSS, 2013; GPS, 2014). The Ghana Police Service is therefore reported to have been overwhelmed in executing their constitutional mandate of providing internal security especially within urban Ghana (Tankebe, 2013).

Despite the continuous increase in the urban population and the reported cases of crime within the Ghanaian urban space since the last decade of the twentieth century and the notable human and logistic limitedness of the Ghana Police Service, the majority (79\%) of urban dwellers perceive of their communities as safe (Global Peace Index (GPI), 2017; Bagson, 2018). It therefore appears uncertain what drives people's perception of safety within an environment of concurrent increase in the pace of urbanisation and reported cases of crime within the Ghanaian urban space. This study critically examines this counter intuitiveness in Kumasi and Tamale metropolises as reminiscent of typical urban dynamics in the Ghanaian urban hierarchy. As the two largest cities within in-land Ghana (GSS, 2014), the postulations of crime and city size (Gaigné \& Zenou, 2015; O’Flaherty \& Sethi, 2015), is hard to ignore and more so reports of rising incidence of crime in large cities is pronounced in developing countries despite the disdain of non-reporting associated with criminal events in the region (UNODC, 2013). According to Gaigné and Zenou (2015) larger cities offer an opportunity for the interaction between wealthier and more crime-prone potential victims, likely smarter perpetrators and a suitable market for stolen goods within a highly heterogeneous environment conceivably limiting police fight against crime. As we spell out the determinants of urban dwellers' constructions of safety in Ghana in the results and discussion sections follows by the conclusions and recommendations thereof, it is prime to demonstrate the theoretical and methodological orientations of the study, respectively.

\section{Theoretical and Conceptual Framework}

The conceptual framework of this study is a derivative of three ecological theories associated with criminological synthesis of the possibility of crime to occur or not. The triangulation was necessitated by the dissimilar urban socio-cultural and the political economic situations of the present study and the North American urban dynamics as preserved in the theories. The collective efforts of the Social Disorganisation Theory (Shaw \& McKay, 1942), Collective Efficacy Theory (Sampson et al., 1997) and Routine Activity Theory (Cohen \& Felson, 1979) give a strong basis to conceptualise the determinants of safety within the Ghanaian urban space. These theories commonly appreciate the correlates of urbanisation and incidence 
of crime but differentially postulate crime prevention strategies and the perception of safety.

The social disorganisation theory (Shaw \& McKay, 1942) demonstrate that neighbourhoods characterised by poverty, residential mobility, ethnic heterogeneity and unemployment are synonymous of breakdown of social organisation and are therefore perceived as crime prone environments as they lack communal spirit to enable residents avert criminogenic tendencies and crime. The wide spread application and hefty affirmation of the theory is eminent in the global north (Kubrin; 2009 Sampson, 2017), generally concluding that the fluidity of norms and values associated with urbanisation dominant in public perception of insecurity.

However, Sampson et al. (1997) propounded the Collective Efficacy Theory to highlight on how social processes, intermingling relationships, influence the occurrence or otherwise of crime. They conceptualised collective efficacy as 'social cohesion among neighbours combined with their willingness to intervene on behalf of the common good' and therefore building communal interest in neighbourhood safety. Aside the communal persuade of neighbourhood safety by the Shaw \& McKay (1942) and Sampson et al. (1997), the Routine Activity Theory (Cohen \& Felson, 1979) postulates that neighbourhood safety dwindles as a suitable target, a motivated offender and an incapable or no guardian intersect within time and space. Thus, a suitable target could be a person/object/place whose immediate environment lowers the risk of offenders' detection whereas a capable guardian has the potential to break the contact between the motivated offender and the suitable target. According to Felson \& Clarke (1995) the effectiveness of a mechanical guardianship, such as alarms, fences and walls, bard wires, CCTVs among others, is enhanced by the presence of a capable human being be it the police, friends or neighbours which Tewksbury \& Mustaine, (2003) categorised as formal or informal guardianship.

Informed by the varied postulations from the three theories reviewed, Figure 1 illustrates how contemporary cities within the concurrence of some global processes (urbanisation, globalisation and neo-liberal trade liberalisation) strive for neighbourhood safe. State and non-state agencies with the common agenda to enable a safe urban space commonly result in two phases of a city or two parallel cities: a socially organised city or a socially disorganised city (Figure 1). The former is characterised by a strong state governing structures capable of equitably making available urban services including the provision of security services, spatial planning and design, and generally resilient and workable urban management policies. To the latter, it is an urban space of social disorganisation, weak governance structures and consequently unequal access to urban services including the capacity to provide internal security as a basic need. Urban space users within such domains 
most commonly encounter high sense of insecurity and largely incapable of inducing communal efforts to achieve a goal such as neighbourhood safety.

Despite the structural and socio-cultural variations that may exist in the two phases of a city or among cities, there are shared intervening factors which attract a common sense of purpose among residents. As shown in Figure 1, such intervening factors include the social and political economy of the related governance structure as well as the underlining religious and cultural dynamics that can push forward some efforts to secure the urban space. In other words, such mediating factors are capable binding forces to social integration (Sampson et al., 1997) and a socially integrated neighbourhood is more likely to widen the gap between the motivated offender and the suitable guardian (Cohen \& Felson, 1979) thus fostering the construction of safety and security.

\section{Figure 1: Conceptual framework on securitisation} of the contemporary urban space

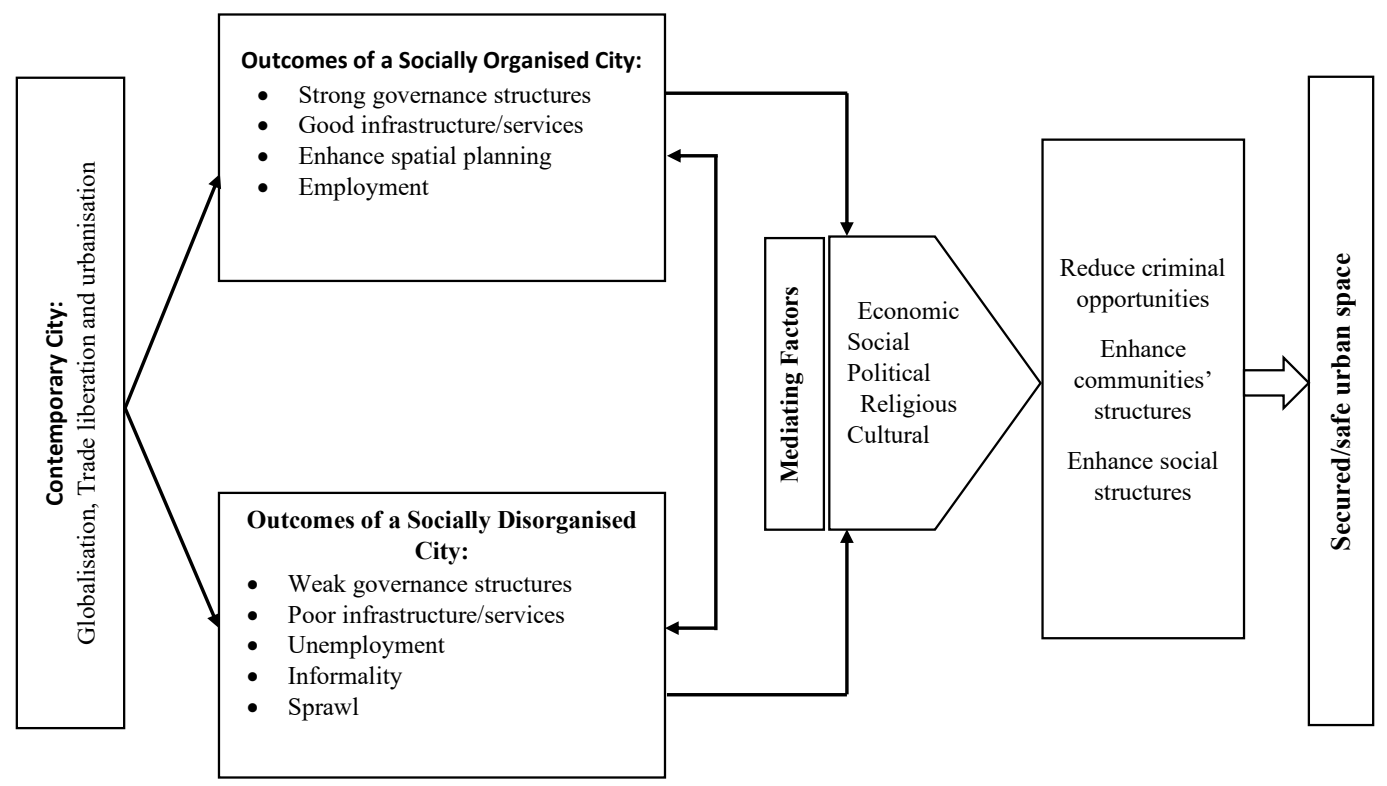

Source: Adapted from Bagson (2018) 


\section{Materials and Methods}

\section{Description of the Study Locations}

In consonance with the methodological orientation of a national project titled 'Exploring Poverty and Crime Nexus in Urban Ghana' - an offshoot of a global project: "safe and inclusive cities" - from which this paper emanates, Kumasi and Tamale, among other two cities (Accra and Sekondi-Takoradi), were purposively selected. Kumasi was purposively selected not because it is one of the two primate cities in Ghana's urban hierarchy, but because scholars have variedly shown evidence of rapid pace of urbanisation in the metropolis inter alia sprawling, vibrant CBD, well connected transport network, and functional economic and industrial hubs (Quagraine, 2011; Poku-Boansi \& Inkoom, 2011; Tontoh, 2011; GSS, 2013; AdjeiMensah, 2014; Koranteng, 2017). The metropolis has an exceptionally higher average population density $(8,075$ persons per sq $\mathrm{km})$ than the national average population density of 103.4 persons per sq km (GSS, 2014). Cognisant of the role of non-state agents in the provision of internal security (Bagson, 2018) and the city-size-crime intricacies (Zeng, 2010) the state appears burdened in the provision of internal security as crime levels increases over time (GPS, 2014) in the city.

On the other hand, as the only metropolis in northern Ghana, the geographical location of Tamale does not only link the Sahelian region of North Africa to southern Ghana, but the city is relatively well connected to its adjoining regions and districts. Even though the Northern Region recorded negative net migration in 2010 (GSS, 2013), Tamale has been a centre of attraction since the government's investment in agriculture in the 1970 (Songsore, 2011). Thus, the city's population more than doubled (54\%) in three decades - 1970 to 2000 (GSS, 2014). Ziem (2013) rated Tamale as the fastest growing city in West Africa and also associated with increase in reported cases of crime (GPS, 2014). The local economy is dominated by the agricultural sector, informal market place and a competitive service sector (GSS, 2014). The relatively large youth population appears skills-trapped to be employed in the formal commercial and the NGOs service sectors hence some scholars (see Bagson \& Owusu, 2016; Oteng-Ababio, et al., 2016) attribute the religious-, political-, and chieftaincy-related unrest to the unskilled youth in the city.

\section{Methodology and Analytic Framework}

The brief review of the background of the study locations stimulates a comparative analysis of the determinants of neighbourhood safety within an exploratory and sequential mixed method design. Hence, the outcomes of the qualitative field data guides the design and collection of the quantitative field data to enhance the 
research data in sync with Teye (2012). As detailed in the method section of previous scholarly works of the national project (Owusu et al., 2016; Oteng-Ababio al et., 2016), three different socio-economic neighbourhoods (lower-, middle-, and upperclass) were selected from each city based on their suitability as documented in Agyei-Mensah \& Owusu (2010). Selected neighbourhoods in Kumasi were: Ahodwo, Oforikrom and Aboabo-Kumasi as upper-, middle - and lower-class neighbourhoods respectively. Similarly, Russian Bungalow, Zogbeli and Aboabo-Tamale represented the upper-, middle - and lower-class neighbourhoods in that order. Subsequently, multi-stage cluster sampling design was employed in the selection of Enumeration Areas (EA) based on each city's proportion of the sum of the population of the two cities. Then, with a random start at a constant interval, 15 households were selected systematically to a sum of 1,335 ( 885 from Kumasi and 450 from Tamale).

A household survey was led by a 54 Key Informants Interviews (KII) and 12 Focus Group Discussions (FGDs) conducted in the two cities. The key informants from each city included: three religious leaders, four opinion leaders, one senior police officer, two youth leaders as well as 'prominent' mallams, diviners and pastors. All interviews and discussions were audio recorded, transcribed and subjected to thematic analysis - sorting and relating respondents' expressions of lived experiences of perceive neighbourhood safety or insecurity. The quantitative data was analysed using binary logistic regression. As required in binary logistic regression (Pallant, 2010), a dichotomised dependent variable was regressed on a mixture of continuous and categorical independent variables (see codes in Table 1). 
Table 1: Codes of the dependent and independent variables

\begin{tabular}{|c|c|c|}
\hline \multirow[t]{2}{*}{ Variables } & \multicolumn{2}{|l|}{ Codes } \\
\hline & Reference categories & Non-reference categories \\
\hline \multicolumn{3}{|l|}{ Dependent variable } \\
\hline Neighbourhood safety & Safe $=1$ & Unsafe $=0$ \\
\hline \multicolumn{3}{|l|}{ Independent variables } \\
\hline \multicolumn{3}{|c|}{ Individual level characteristics } \\
\hline Period of residence & Continuous variable & \\
\hline Age & Continuous variable & \\
\hline Gender & Male $=1$ & Female $=0$ \\
\hline Marital status & Married = 1 & Not married $=0$ \\
\hline Consumption income & 1,501 and above $=1$ & $1-1,500=0$ (Cedis) \\
\hline Level of education & Above high school = 1 & High school and below $=0$ \\
\hline Shared dwelling unit & Yes $=1$ & No $=0$ \\
\hline \multicolumn{3}{|l|}{$\begin{array}{l}\text { Neighbourhood level } \\
\text { characteristics }\end{array}$} \\
\hline Street light & Yes $=1$ & $\mathrm{No}=\mathrm{o}$ \\
\hline Police patrol & Yes $=1$ & $\mathrm{No}=\mathrm{o}$ \\
\hline Level of crime & High = 1 & Low $=0$ \\
\hline Youth disorder & Problem $=1$ & Not a problem $=0$ \\
\hline Willingness to intervene & Continuous variable & \\
\hline Social cohesion & Continuous variable & \\
\hline \multicolumn{3}{|c|}{$\begin{array}{l}\text { Neighbourhood socio-economic } \\
\text { Status }\end{array}$} \\
\hline Middle & Lower & \\
\hline \multicolumn{3}{|l|}{ Upper } \\
\hline Lower & Middle & \\
\hline Upper & & \\
\hline
\end{tabular}

Source: adapted from Bagson (2018)

\section{Measures of Variables}

\section{Dependent Variable}

We examined one dichotomised dependent variable in this analysis. The variable was dichotomised from a general Likert type question "how safe do you feel in 
your community currently?" with options ranging from very safe to very unsafe. The descriptive statistics indicated very limited uncertainty or neutrality among respondents from both cities and that well-matched the broad categorisation of the responses to safe and unsafe neighbourhoods (Table 1) to enable it best fit the dichotomised dependent variable requirements of binary logistic regression.

\section{Independent Variables}

As derivatives of the theoretical and conceptual frameworks, the independent variables were a mixture of categorical and continuous variables grouped into individual - and neighbourhood-levels characteristics (Table 1). The period of stay within a neighbourhood and age of the respondents were collected as continuous variables. These two variables appear very important in estimating how aging and length of stay in a neighbourhood contribute to perception of safety. The rest of the individual level variables are: gender, marital status, consumption income, level of education, and living in a shared apartment were collected as categorical variables and subsequently dichotomised.

The neighbourhood level variables were represented by two composite variables derived from two Likert scales. The first is willingness to intervene. This variable was constructed from five item Likert scale which required that respondents rank (from strongly agree to strongly disagree) the following statements about their neighbourhood: neighbours are willing to help one another, this is a close-knit neighbourhood, people in this community can be trusted, people in this community generally do not get along with each other, and people in this neighbourhood do not share the same values. Prior to the construction of the composite variable, all negative statements were made positive so that increase in the mean value of the composite variable results in increase in the willingness of neighbours to intervene in the course of crime with a Cronbach's alpha value of 0.78 . Secondly, in estimating the contributions of social cohesion to the perception of neighbourhood safety, respondents were asked to respond to the following five item Likert scale: how often do you engage in the following statements in your neighbourhood? borrowing or exchanging things with neighbours; asking someone from the neighbourhood over to your house or go to their house for a meal; ask your neighbour for help such as taking care of a child; going out for an evening with someone from the neighbourhood; or talking to someone in the neighbourhood about shopping.

With regard to the other neighbourhood characteristics, respondents were asked to answer yes or no as to whether there are street lights, they require police surveillance as well as whether level of crime is high or low and if youth disorder 
is a problem or not in the community. Following the analysis of these variables via binary logistic regression, the results are due for discussion in the next section.

\section{Results and Discussion}

\section{Demographic Characteristics of Respondents}

Despite the difference in socio-cultural and political economy situations of the two cities, their demographic characteristics (Table 2) appear the same except in two independent variables. Whereas the majority (54\%) of respondents were females in Kumasi, in Tamale the male respondents formed the majority (57\%). This gave a fair male to female ratio for the sake of a balance gender based lived experiences in the perception of neighbourhood safety. Secondly, respondents' perceptions of youth disruption as a problem within neighbourhoods varied. Whilst 62 percent of the respondents in Kumasi indicated that youth disruption was a problem in the pursuit of safety of life and property, 64 percent of the respondents in Tamale perceive the opposite. Further analysis within the binary logistic model was informative on how the demographic differences and similarities explained the variations in the perceptions of neighbourhood safety within the two cities.

\section{Determinants of Neighbourhood Safety in Kumasi Metropolis}

In Kumasi, three of the seven individual level demographic characteristics appear statistically significant in determining people's perception of safety of life and property. As shown in Table 3, a year increase in age results in 1.023 times the odds of perceiving the neighbourhood safe. This means that as age increases by one, an individual is 51 percent more likely to perceive the neighbourhood as safe similar to findings by Lee and Hilinski-Rosick (2012) that older people perceive a higher sense of security within neighbourhood than younger people. On the contrary, Pryce et al. (2018) indicates that an individual's vulnerability positively correlates with age and the perception of insecurity. Nevertheless, conclusion from our FGD affirmed that increase in age reinforces identity and self-confidence in neighbourhood's safety. Hence, consciousness of the immediate environment most likely enhances a guardian capability and provides a wedge between a suitable target and a potential offender as advanced by Cohen and Felson (1979). With respect to gender, males are 1.88 times more likely than females to perceive their neighbourhood as safe. Hence, males are 65 percent more likely than females to perceive their neighbourhood as safe. The tendency of demonstrating insecurity in females than in males is confirmed by Pryce et al. (2018). 
Table 2: Descriptive statistics of individual and neighbourhood characteristics

\begin{tabular}{|c|c|c|c|}
\hline \multirow{2}{*}{\multicolumn{2}{|c|}{$\begin{array}{l}\text { Variables } \\
\text { Kumasi (\%) }\end{array}$}} & \multicolumn{2}{|c|}{ Research locations } \\
\hline & & \multirow{2}{*}{$\begin{array}{l}\text { Tamale (\%) } \\
41^{*} \\
\end{array}$} & \multirow[b]{2}{*}{$41^{*}$} \\
\hline Mean age & & & \\
\hline Mean length of residence & & $22^{*}$ & $23^{*}$ \\
\hline Mean willingness to intervene & & $9.7^{* *}$ & $10.4^{* *}$ \\
\hline Mean social cohesion & & $13.9^{* *}$ & $12.8^{* *}$ \\
\hline \multirow[t]{2}{*}{ Gender } & Male & 41.4 & $54 \cdot 3$ \\
\hline & Female & 58.6 & 45.7 \\
\hline \multirow[t]{2}{*}{ Marital status } & Married & 59.9 & 68.4 \\
\hline & Not married & 40.1 & 31.6 \\
\hline \multirow[t]{2}{*}{ Mean consumption income } & $1-1500$ & 96.9 & 85.1 \\
\hline & $>1502$ & 3.1 & 14.9 \\
\hline \multirow[t]{2}{*}{ Level of education } & High school and below & 92.5 & 77.4 \\
\hline & Above high school & 7.5 & 22.6 \\
\hline \multirow[t]{2}{*}{ Shared dwelling unit } & Yes & 87.1 & 89.8 \\
\hline & No & 12.9 & 10.2 \\
\hline \multirow[t]{2}{*}{ Street light } & Yes & 93.9 & 81.8 \\
\hline & No & 6.1 & 18.2 \\
\hline \multirow[t]{2}{*}{ Need police patrol } & Yes & 96.2 & 90.5 \\
\hline & No & 3.8 & 9.5 \\
\hline \multirow[t]{2}{*}{ Level of crime } & High & 55.1 & 61.3 \\
\hline & Low & 44.9 & 38.7 \\
\hline \multirow[t]{2}{*}{ Youth disorder } & Problem & 61.9 & 36.4 \\
\hline & Not a problem & 38.1 & 63.6 \\
\hline
\end{tabular}

Source: adapted from Bagson, 2018

Notes: ${ }^{*}$ in years; ${ }^{* *}$ no units

A male youth leader in Ahodwo opined that the considerably high sense of security in male is obvious in their likelihood to defend when they feel insecure than females will be ready to do. In a similar expression, a 35-year-old resident of Aboabo-Kumasi said:

I do not wait to fight crime, but I take personal measures such as staying indoors at night and avoiding isolated places-since these are times and places where crime is likely to occur. So this makes me feel safe in 
the neighbourhood. (Personal interview with 35-year-old female, youth leader, Aboabo-Kumasi, 23/02/2017)

This reaffirms the view that people are likely to have a higher sense of safety within a familiar environment contrary to Wrigley-Asante (2016) that some crimes are dominant among acquaintances. To further understand how familiarity and acquaintances affect the construction of safety, we examine if living in a shared dwelling apartment enhances perception of safety. The regression results show that living in a shared dwelling unit increase the perception of safety by 1.87 times than not living in a shared dwelling unit. A female resident in Oforikrom confirmed in her expression that:

We are five different households in this compound, and almost all day long someone will be within the compound-and that is a form of guarding the place. Members also demonstrate the willingness to assist whenever one of us is a victim of crime or to intervene to stop crime from occurring; and this makes me feel safe, especially in the compound. (Personal interview with 45-year-old female, opinion leader, Oforikrom, 24/02/2017)

This means that ease of access to support within the neighbourhood adds to perception of safety of life and property similar to findings by McMahon et al. (2015) and Coker (2011). 
Table 3: Estimates of logistic regression of neighbourhood safety on demographic and neighbourhood conditions in Kumasi metropolis

\begin{tabular}{|c|c|c|c|c|c|}
\hline Variables & Odds & Std. Err. & $\mathrm{P}>\mathrm{z}$ & \multicolumn{2}{|c|}{ [95\% Conf. Interval] } \\
\hline \multicolumn{6}{|l|}{$\begin{array}{l}\text { Demographic } \\
\text { characteristics }\end{array}$} \\
\hline Period of residence & 0.993 & 0.006 & 0.332 & 0.980 & 1.006 \\
\hline Age & 1.023 & 0.007 & 0.004 & 1.007 & 1.038 \\
\hline Male & 1.880 & 0.350 & 0.001 & 1.303 & 2.710 \\
\hline Married & 0.822 & 0.157 & 0.306 & 0.564 & 1.197 \\
\hline Consumption income & 0.968 & 0.529 & 0.953 & 0.331 & 2.828 \\
\hline Level of education & 1.142 & 0.399 & 0.704 & 0.575 & 2.268 \\
\hline Shared dwelling unit & 1.873 & 0.557 & 0.035 & 1.046 & 3.356 \\
\hline \multicolumn{6}{|c|}{ Neighbourhood conditions } \\
\hline Street light & 1.133 & 0.447 & 0.753 & 0.522 & 2.455 \\
\hline Police patrol & 0.087 & 0.091 & 0.020 & 0.011 & 0.679 \\
\hline Level of crime & 0.256 & 0.055 & 0.000 & 0.166 & 0.392 \\
\hline Youth disorder & 1.831 & 0.419 & 0.008 & 1.168 & 2.868 \\
\hline Willingness to intervene & 1.146 & 0.042 & 0.000 & 1.066 & 1.230 \\
\hline Social cohesion & 0.88 & 0.032 & 0.000 & 0.819 & 0.945 \\
\hline \multicolumn{6}{|l|}{$\begin{array}{l}\text { Neighbourhood socio- } \\
\text { economic status }\end{array}$} \\
\hline \multicolumn{6}{|l|}{ Reference category: Lower } \\
\hline Middle & 0.869 & 0.175 & 0.489 & 0.585 & 1.291 \\
\hline Upper & 1.412 & 0.649 & 0.453 & 0.573 & 3.479 \\
\hline \multicolumn{6}{|l|}{ Reference category: Middle } \\
\hline Lower & 1.149 & 0.231 & 0.489 & 0.774 & 1.707 \\
\hline Upper & 1.623 & 0.733 & 0.283 & 0.670 & 3.935 \\
\hline _cons & 21.117 & 28.411 & 0.023 & 1.511 & 295.003 \\
\hline
\end{tabular}

Source: Adapted from Bagson, 2018 
In assessing neighbourhood conditions, respondents were asked if they needed police surveillance within the neighbourhoods. It was realised that respondents who needed police presence were o.086 times less likely to perceive their neighbourhood as safe than those who needed no police patrol in the neighbourhood. Thus, even with the negative public perception of the Ghana Police Service to execute their mandate (Tankebe, 2013), some confidence still exist for the police to provide internal security. A key informant in Ahodwo expressed some confidence in the police as stated:

Even just a random or periodic movement by the police within the community can ward off crime, and not necessarily the major road patrols that we see them [police] do sometimes. (Personal interview with 65-year-old man, opinion leader, Ahodwo, 12/11/2016)

With respect to the effects of level of crime on the perception of safety, respondents with perceived high level of crime are 0.255 less likely to perceive their neighbourhood as safe than those who perceive low level of crime in the like of Coker et al. (2011). Subsequently, respondents who perceive youth disruption a problem in their neighbourhood were 1.831 times more likely to perceive their neighbourhood as safe than those who did not. This was confirmed by a religious leader in Aboabo-Kumasi in the following statement:

It is unfortunate that we have a number of our youth unemployed and therefore hanging around in the neighbourhood, but I can tell you that they watch over the community for any intrusion or the commission of crime (Personal interview with 41-year-old man, opinion leader, Aboabo-Kumasi, 14/11/2016).

In other words, youth unemployment appears to enhance the security situation in the community as guardianship is omnipresent.

Furthermore, we assessed the opinion of respondents' willingness to intervene in youth deviant behaviour and their perception of safety. The model revealed that, a unit increase in the willingness to intervene results in 1.146 times more likely to perceive a safe neighbourhood. This finding is in sync with Sampson et al.'s (1997) that social capital is paramount in forming people's perception of safety in a vicinity but contradict Shaw and McKay's (1942) postulation of a more likelihood of idle youth getting into crime than averting it. Our interest was drawn to the level of cohesion and trust among neighbours and its contribution to people's construction of safety. The model indicates that, a unit increase in cohesion and trust in Kumasi result in 0.880 times less the odds of perceiving a neighbourhood as safe. This means that people have limited level of cohesion and trust among themselves 
possibly reflecting the fluidity of the urban population and a degenerative primary relationship within the metropolis.

In comparing residents' perception of safety among the three different socioeconomic neighbourhoods, the model revealed that residents of the middleclass socio-economic neighbourhood are 0.869 times less likely to perceive their neighbourhood as safe, than residents of the lower-class socio-economic neighbourhood but the difference was not statistically significant. Notably, the similar socio-cultural characteristics and blur boundaries between the two neighbourhoods as reported in Owusu and Oteng-Ababio, (2015) might have accounted for the statistically insignificant differences recorded in this study. Relatedly, residents of the upper-class socio-economic neighbourhood appears 1.412 times more likely to perceive their neighbourhood as safe compared to the lowerclass socio-economic neighbourhood and 62 percent more likely to perceive their neighbourhood as safe compared with residents of the middle-class community but the difference is not statistically significant. In all, the statistically insignificant differences between the three neighbourhoods demonstrating a possible spatial but not necessarily social integrations across the neighbourhoods which narrows the gap between a motivated offender and a suitable target as asserted by Cohen and Felson (1979). Despite the statistically insignificant differences among neighbourhoods in Kumasi, the upper-class residential area is considered the safest place, followed by the lower-class and middle-class socio-economic neighbourhoods respectively.

\section{Determinants of Neighbourhood Safety in Tamale Metropolis}

In Tamale, two of the seven demographic characteristics appear statistically significant (Table 4). Firstly, the model indicates that males are 0.026 times less likely to perceive the neighbourhood as safe than females. This finding points differently to the scholarly work of Britto et al. (2018), but was reaffirmed in a FGD in Aboabo-Tamale as the discussants concluded:

We cannot hide away from the periodic political-, chieftaincy-, and religious-related misunderstanding that occur in our communities; and these usually involve men, because women do not go to war. Hence men are more affected than women, and men will therefore feel unsafe compared with women (FGD, Aboabo-Tamale, 17/02/2017).

Secondly, residents of a multiple household dwelling unit are 1.945 times more likely to perceive their neighbourhood safer than residents of single household dwelling unit. Subsequently, three of the six community level characteristics 
attained statistical significance in residents' perception of safety. As shown in Table 4, residents who indicated their desire for police patrol in the communities were o.327 times less likely to perceive their neighbourhood safe compared to resident who required no police patrol. Thus, residents who require police patrol within the community are 25 percent more likely to say their neighbourhood is unsafe compared to those who need no police patrol. Secondly, respondents who expressed opinion that youth disruption was a problem were 0.184 times less likely to say their neighbourhood is safe - which is consistent with Frimpong's (2016) analysis of fear of crime in the Sekondi-Takoradi metropolis.

Table 4: Estimates of logistic regression of neighbourhood safety on demographic and neighbourhood conditions in Tamale metropolis

\begin{tabular}{|c|c|c|c|c|c|}
\hline Variables & Odds & Std. Err. & $\mathrm{P}>\mathrm{z}$ & \multicolumn{2}{|c|}{ [95\% Conf. Interval] } \\
\hline \multicolumn{2}{|c|}{ Demographic characteristics } & & & & \\
\hline Period of residence & 1.010 & 0.018 & 0.557 & 0.976 & 1.045 \\
\hline Age & 1.006 & 0.017 & 0.720 & 0.973 & 1.040 \\
\hline Male & 0.026 & 0.606 & 0.006 & 0.055 & 0.277 \\
\hline Married & 0.799 & 0.364 & 0.625 & 0.327 & 1.955 \\
\hline Consumption income & 1.074 & 0.946 & 0.935 & 0.191 & 6.039 \\
\hline Level of education & 0.519 & 0.255 & 0.183 & 0.198 & 1.362 \\
\hline Shared dwelling unit & 1.945 & 1.624 & 0.025 & 0.018 & 0.045 \\
\hline \multicolumn{6}{|c|}{ Neighbourhood conditions } \\
\hline Street light & 0.692 & 0.476 & 0.593 & 0.179 & 2.666 \\
\hline Police patrol & 0.327 & 0.357 & 0.007 & 0.038 & 0.784 \\
\hline Level of crime & 1.109 & 0.592 & 0.845 & 0.389 & 3.159 \\
\hline Youth disorder & 0.183 & 0.132 & 0.019 & 0.044 & 0.755 \\
\hline Willingness to intervene & 1.321 & 0.137 & 0.007 & 1.077 & 1.619 \\
\hline Social cohesion & 0.918 & 0.092 & 0.400 & 0.754 & 1.119 \\
\hline \multicolumn{6}{|c|}{ Neighbourhood socio-economic status } \\
\hline \multicolumn{6}{|l|}{ Reference category: Lower } \\
\hline Middle & 2.963 & 1.458 & 0.027 & 1.129 & 7.773 \\
\hline Upper & 0.039 & 0.071 & 0.077 & 0.001 & 1.416 \\
\hline \multicolumn{6}{|l|}{ Reference category: Middle } \\
\hline Lower & 0.337 & 0.166 & 0.027 & 0.128 & 0.885 \\
\hline Upper & 0.013 & 0.024 & 0.015 & 0.001 & 0.436 \\
\hline _cons & 29.847 & 70.019 & 0.148 & 0.300 & 2962.933 \\
\hline
\end{tabular}

Source: adapted from Bagson, 2018 
Thirdly, with an increase in one unit, respondents who show willingness to intervene in the course of crime were 1.321 times more likely to perceive their community as safe compared to those with no willingness to intervene in the course of crime. This means that people who are willing to intervene in crime have 57 percent greater likelihood to say their neighbourhood is safe which affirms Janisz's (2014) conclusion that people assume higher sense of safety when they know that others can intervene in the course of crime in their neighbourhood. Furthermore, if cohesion and trust among resident is increase by one unit, residents' perception of safety is decrease by 0.92 times. This emerged as counter intuitive because residents who asserts high sense of cohesion and trust appears 48 percent unsafe but could also imply that the increasing level of insecurity is inducing a situation OtengAbabio et al. (2016) associated with Tamale as calm but tension-packed.

Finally, in comparing total perception of safety across the lower-, middle - and upper-class socio-economic neighbourhoods, the model indicates that residents of the middle-class residential area are 2.96 times more likely to perceive their community safer (75\%) than the lower-class socio-economic neighbourhood at statistically significant level. However, residents of the upper-class neighbourhood are 0.039 times and 0.013 times less likely to perceive their community as safe compared to that of the lower - and middle-class socio-economic neighbourhoods respectively. Hence, perception of safety at the neighbourhood level in Tamale show that the safest place of resident is the middle-class neighbourhood followed by the lower-class community whilst the least safe place of resident is the upper-class socio-economic neighbourhood.

\section{Conclusion}

General perception of safety of life and property is high (79\%) in both cities but there are some convergence and divergence individual and neighbourhood levels characteristics that determined residents' perception of safety in a nonexclusive manner. The common determinant of safety within the individual level characteristics is that perception of safety is more likely among residents of multiple-household apartments than single dwelling units. Dissimilarly, whilst individual level determinants of safety in Kumasi include: increase in age, and being male, in Tamale, females are safer than males in their neighbourhoods. Secondly, common statistically significant determinants of safety at the neighbourhood level in both cities include: the need for police patrol, youth disorder, willingness to intervene in the course of crime and social cohesion. However, whilst level of crime is a statistically significant determinant of safety in Kumasi, it is not the case within the Tamale metropolis. In all, whereas the safest place of residence in Kumasi 
is the upper-class neighbourhood, in Tamale it is the middle-class residential area. On the other hand, the least safe place in Kumasi is the middle-class socio-economic neighbourhood and in Tamale it is the upper-class residential area.

\section{Recommendation}

Despite the differences and similarities unravelled as determinants of safety of life and property between and within the two cities, the study recommends collaborative efforts between traditional authorities and the Ghana Police Service to enable establish community police units and community watch committees to enhance neighbourhood safety base on local knowledge. Secondly, attempts should be made by the government to encourage each metropolitan, municipal and district assemblies to recruit and train their own police to properly fit the foundation of community policing.

\section{Acknowledgement}

This work was carried out with the financial support from the UK Government's Department for International Development (DFID) and the International Development Research Centre (IDRC), Ottawa, Canada.

\section{References}

Adjei-Mensah, C. (2014). Is Kumasi still a Garden City? Land use analysis between 1980-2010. Journal of Environment and Ecology, 5(2), pp. 89-107.

Agyei-Mensah, S. and Owusu, G. (2010). Segregated by neighbourhoods? A portrait of ethnic diversity in the neighbourhoods of the Accra Metropolitan Area, Ghana. Population, Space and Place, 16(6), pp. 499-516.

Bagson, E. (2018). Analysis of informal crime prevention strategies in urban Ghana: the case of Kumasi and Tamale, doctoral dissertation, University of Ghana.

Bagson, E. and Owusu, A.Y. (2016). Securing the urban space: On whose terms? Insights from poverty and crime baseline survey in Tamale, Ghana. Ghana Journal of Geography, 8(1), pp. 124-147.

Britto, S., Stoddart, D., and Ugwu, J. (2018). Perceptually contemporaneous offenses: Gender and fear of crime among African-American university students. Journal of Ethnicity in Criminal Justice, 16(2), pp. 117-136.

Cohen, L. E. and Felson, M. (1979). Social change and crime rate trends: A routine activity approach. American Sociological Review, 44(4), pp. 588-608. 
Coker, A.L., Cook-Craig, P.G., Williams, C.M., Fisher, B.S., Clear, E.R., Garcia, L.S., and Hegge, L.M. (2011). Evaluation of Green Dot: An active bystander intervention to reduce sexual violence on college campuses. Violence against Women, 17, pp. 777-796.

Felson, M. and Clarke, R.V. (1995). Routine precautions, criminology, and crime prevention. In Barlow, H.D. and Decker, S.H. (Eds.), Crime and Public Policy: Putting Theory to Work (pp. 179-90). Philadelphia: Temple University Press.

Frimpong, L.K. (2016). Geography of fear of crime: Examining intra-urban differentials in Sekondi-Takoradi Metropolis, Ghana. Ghana Journal of Geography, 8(1), pp. 79-102.

Gaigné, C. and Zenou, Y. (2015). Agglomeration, City Size and Crime. European Economic Review. Elsevier. 80 (C), pp. 62-82.

Ghana Police Service (2014): Statistics and information technology unit, CID Headquarters, Accra.

GPI (Global Peace Index) (2017). Measuring Peace in a Complex World. Institute For Economic and Peace.

GSS (Ghana Statistical Service) (2013). 2010 Population \& Housing Census Summary Report of Final Results. Ghana Statistical Service, Accra, Sakoa Press Limited

GSS (Ghana Statistical Service) (2014). 2010 Population and Housing Census Summary Report of Final Results. Ghana Statistical Service, Accra: Sakoa Press Limited.

Janisz, A. (2014). Crimes, Causality, and Theories. Criminal Environmental Studies, 47(1), pp. 57-69.

Koranteng, A. (2017). Competitive Land Use/Cover of Kumasi and its Environs Based on Satellite Imagery Studies. In International Conference on Applied Science and Technology Conference Proceedings, 1(1), pp. 208-219.

Kreager, D.A., Lyons, C.J. and Hays, Z.R. (2011). Urban revitalisation and Seattle crime, 1982-200o. Social Problems, 58(4), pp. 615-639.

Kubrin, C. E. (2009). Social disorganisation theory: Then, now, and in the future. In Handbook on Crime and Deviance. New York: Springer, pp. 225-236.

Lange, F.E. (2009). Urban Governance: An essential determinant of city development. Theory and Practice: Scientific Series.

Lee, D.R., and Hilinski-Rosick, C.M. (2012). The role of lifestyle and personal characteristics on fear of victimization among university students. American Journal of Criminal Justice, 37(4), 647-668. 
Maguire, M. (2012). Criminal statistics and the construction of crime. The Oxford Handbook of Criminology, 5, pp. 206-244.

McMahon, S., Winter, S.C., Palmer, J., Postmus, J., Peterson, N.A., Zucker, S.R., and Koenick, R.A. (2015). A randomised controlled trial of a multi-dose bystander intervention program using peer education theatre. Health Education Research, 30, pp. 554-568.

Moser, C. (2018). Foreword. In Salahub, J.E., Gottsbacher, M. and de Boer, J. (Eds.), Social Theories of Urban Violence in the Global South: Towards Safe and Inclusive Cities. London: Routledge.

O'Flaherty, B. and Sethi, R. (2015). Urban Crime. Handbook of Regional and Urban Economics, 5, pp. 1519-1621.

Oteng-Ababio, M. and Melara, J.E.A. (2014). Paradigm of mediocrity: Poverty and risk accumulation in urban Africa-The case of Korle Gonno, Accra. Journal of Urbanism: International Research on Place making and Urban Sustainability, 7(1), pp. 45-61.

Oteng-Ababio, M., Owusu, G., Wrigley-Asante, C. and Owusu, A. (2016). Longitudinal analysis of trends and patterns of crime in Ghana (1980-2010): A new perspective. African Geographical Review, 35(3), pp. 193-211.

Owusu, G. and Oteng-Ababio, M. (2015). Moving unruly contemporary urbanism toward sustainable urban development in Ghana by 2030. American Behavioural Scientist, 59(3), pp. 311-327.

Owusu, G., Oteng-Ababio, M., Owusu, A.Y. and Wrigley-Asante, C. (2016). Can poor neighbourhoods be correlated with crime? Evidence from urban Ghana. Ghana Geographical Journal, 8(1), pp. 11-31.

Pacione, M. (2009). Urban Geography: A Global Perspective. New York: Routledge.

Pallant J. (2010). SPSS Survival Manual: A step by step guide to data analysis using SPSS. 4 edition. Maidenhead: Open University Press.

Poku-Boansi, M. and Inkoom, D.K.B. (2011). Urbanisation and human security in the Kumasi Metropolis. In Adarkwa, K.K. (Ed.), Future of the Tree: Towards growth and Development of Kumasi (pp.234-248). Kumasi: University Printing Press.

Potts, D. (2009). The slowing of sub-Saharan Africa's urbanisation: Evidence and implications for urban livelihoods. Environment and Urbanisation, 21, pp. 253259.

Potts, D. (2012). Whatever happened to Africa's rapid urbanisation? (Counterpoint). London, England: Africa Research Institute. Retrieved from http:// 
africaresearchinstitute.org/newsite/wp-content/uploads/2013/o3/Whateverhappened-to-Africas - rapidurbanisation.pdf

Pryce, D.K., Wilson, G., and Fuller, K. (2018). Gender, age, crime victimisation, and fear of crime: findings from a sample of Kenyan College students. Security Journal, 31(4), pp. 1-20.

Quagraine, V.K. (2011). Urban landscape depletion in the Kumasi Metropolis. In Adarkwa, K. K. (Ed.), Future of the Tree: Towards Growth and Development of Kumasi (pp. 212-233). Kumasi: University Printing Press.

Sampson, R.J., Raudenbush, S. W. \& Earls, F. (1997). Neighbourhoods and Violent Crime: A multilevel study of collective efficacy. Science, 277(5328), pp. 918-924.

Sampson, R.J. (2017). Family management and child development: Insights from social disorganization theory. In McCord, J. (Ed.), Facts, frameworks, and forecasts (pp. 63-94). New York: Routledge.

Shaw, C.R. and McKay. H. D. (1942). Juvenile Delinquency and Urban Areas: A Study of Rates of Delinquents in Relation to Differential Characteristics of Local Communities in American Cities. Chicago: University of Chicago Press.

Songsore, J. (2009). The Urban Transition in Ghana: Urbanisation, National Development and Poverty Reduction. Legon-Accra: University of Ghana.

Songsore, J. (2011). Regional Development in Ghana: The Theory and the Reality. Accra: Woeli Publishing Services.

Tankebe, J. (2013). Viewing things differently: The dimensions of public perceptions of police legitimacy. Criminology, 51(1), pp. 103-135.

Tewksbury, R. and Mustaine, E.E. (2003). College students' lifestyles and selfprotective behaviours: Further considerations of the guardianship concept in routine activity theory. Criminal Justice and Behaviour, 30(3), pp. 302-327.

Teye, J.K. (2012). Benefits, challenges, and dynamism of positionalities associated with mixed methods research in developing countries: Evidence from Ghana. Journal of Mixed Methods Research, 6(4), pp. 379-391.

Tontoh, A.G. (2011). A study to ascertain the growth situation of the Kumasi Metropolitan area (KMA): A remote sensing approach. Master's thesis, Department of Geomatic Engineering, Kwame Nkrumah University of Science and Technology, Kumasi.

UN-Habitat (2010). The State of African Cities 2010: Governance, Inequality and Urban Land Markets. Available at: Nairobi: United Nations Human Settlements Programme https://www.citiesalliance.org/sites/citiesalliance.org/files/ UNH_StateofAfricanCities_2010.pdf. 
Un-Habitat (2012). Enhancing Urban Safety and Security: Global Report on Human Settlements 2007. Routledge.

UNDESA/PD (United Nations Department of Economic and Social Affairs. Population Division) (2012). World Urbanisation Prospects: The 2011 revision. New York: United Nations.

United Nations (2014). World urbanisation prospects: The 2014 revision, highlights. Department of Economic and Social affairs. Population Division, United Nations.

United Nations, Office on Drugs and Crime - UNODC. (2013). Global Study on Homicide. Trends, Context, Data. UNODC Research and Trend Analysis Branch

Wrigley-Asante, C. (2016). Gendered perception of crime and safety: Insights from different socio-economic urban neighbourhoods in Ghana. Ghana Journal of Geography, 8(1), pp. 103-123.

Zeng, Y. (2010). Demography - volume II. Oxford, United Kingdom, EOLSS Publications

Ziem J (2013). Tamale - West Africa's fastest growing city. The daily dispatch newspaper. Access on 24/o6/2019 from https://www.ghanaweb.com/GhanaHomePage/ features/Tamale-West-Africa-s-Fastest-Growing-City-270959 